The Art of Appreciation 
Research for chapters $I-3$ and $5-7$ was funded by a British Academy postdoctoral fellowship. Research for chapter 4 was funded by an Arts and Humanities Research Council postgraduate award (ref. AH/I5OII $85 /$ I).

Support for this book was generously provided by the AMS 75 PAYS Endowment of the American Musicological Society, supported in part by the National Endowment for the Humanities and the Andrew W. Mellon Foundation.

The publisher and the University of California Press Foundation also gratefully acknowledge the generous support of the Richard and Harriett Gold Endowment Fund in Arts and Humanities. 


\section{The Art of Appreciation}

Music and Middlebrow Culture

in Modern Britain

\section{Kate Guthrie}

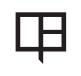

UNIVERSITY OF CALIFORNIA PRESS 
University of California Press

Oakland, California

(C) 202 I by Kate Guthrie

Library of Congress Cataloging-in-Publication Data

Names: Guthrie, Kate, I987- author.

Title: The art of appreciation : music and middlebrow culture in modern Britain / Kate Guthrie.

Other titles: California studies in 2oth-century music ; 30.

Description: Oakland, California : University of California Press, [202I] I Includes bibliographical references and index.

Identifiers: LCCN 202005 I 224 (print) I LCCN 202005 I 225 (ebook) | ISBN 978052035 I677 (cloth) |

ISBN 9780520975897 (epub)

Subjects: LCSH: Music-Social aspects-Great BritainHistory-2oth century. I Music appreciation-Great Britain-History-2oth century.

Classification: LCC ML3917.G7 G87 202 I (print) I

LCC ML 39I7.G7 (ebook) I DDC 780.94I/0904-dc23

LC record available at https://lccn.loc.gov/202005 I 224

LC ebook record available at https://lccn.loc.gov/202005 I 225

Manufactured in the United States of America

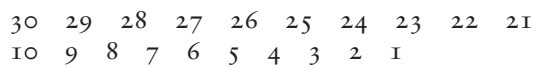


To Adam, in deep appreciation of all your support 
